\title{
DEVELOPMENT OF A STATE POLICY OF SOCIAL ADAPTATION OF DISABLED PERSONS IN UKRAINE
}

\author{
Генріх Казарян \\ РОЗРОБКА ДЕРЖАВНОЇ ПОЛІТИКИ СОЦІАЛЬНОЇ АДАПТАЦІї ОСІБ \\ З ІНВАЛІДНІСТЮ В УКРАЇНІ
}

\author{
Генрих Казарян

\section{РАЗРАБОТКА ГОСУДАРСТВЕННОЙ ПОЛИТИКИ СОЦИАЛЬНОЙ АДАПТАЦИИ ЛИЦ С ИНВАЛИДНОСТЬЮ В УКРАИНЕ}

Directions of elaboration of the policy of social and economic adaptation of disabled persons in Ukraine are analyzed within the article. Current trends in the implementation of the state policy in the field of social and economic support of disabled persons are analyzed. Detailed attention is paid to the definition of basic provisions of the institutional regulation of social and economic provision of disabled persons, justification for such regulation measures, which were combined into two groups: active and passive. In addition, within the article, main measures for the formation of an inclusive educational space are defined and substantiated, issues of the access to education for disabled persons, formation of the policy of their professional training, retraining and advanced training are considered, In particular, an analysis of the peculiarities of the existing system functioning of vocational training of unoccupied population and unemployed disabled persons is conducted.

Keywords: inclusion; inclusive education; policy of social adaptation of disabled persons; inclusive educational space; system of social and economic support of disabled persons.

References: 10.

У статті проаналізовано напрямки розробки політики соиіально-економічної адаптачії осіб з інвалідністю в Україні. Проаналізовано сучасні тендениії реалізації державної політики у сфері сочіально-економічного забезпечення осіб з інвалідністю. Детальна увага приділена визначенню базових положень інституційного регулювання сочіально-економічного забезпечення осіб з інвалідністю, обгрунтуванню заходів такого регулювання, які були згруповані в дві групи: активні та пасивні. Також у статті визначено та обгрунтовано основні заходи формування інклюзивного освітнього простору, розглядаються питання доступності освіти для осіб з інвалідністю, формування політики їх професійної підготовки, перепідготовки та підвищення кваліфікаиії. Зокрема, проведено аналіз особливостей функціонування існуючой системи професійного навчання незайнятих та безробітних осіб з інвалідністю.

Ключові слова: інклюзія; інклюзивне навчання; політика сочіальної адаптації осіб з інвалідністю; інклюзивний освітній простір; система сочіально-економічного забезпечення осіб з інвалідністю.

Бібл.: 10.

В статье проанализированы направления разработки политики соииально-экономической адаптации лиц с инвалидностью в Украине. Проанализированы современные тенденции реализации государственной политики в сфере соииально-экономического обеспечения лии с инвалидностью. Подробная внимание уделено определению базовых положений институционального регулирования соииально-экономического обеспечения лии с инвалидностью, обоснованию мероприятий такого регулирования, которые были сгруппированы в две группы: активные и пассивные. Также в статье определены и обоснованы основные мероприятия формирования инклюзивного образовательного пространства, рассматриваются вопросы доступности образования для лии с инвалидностью, формирование политики их профессиональной подготовки, переподготовки и повышения квалификачии. В частности, проведен анализ особенностей функиионирования существующей системы профессионального обучения незанятых и безработных с инвалидностью.

Ключевые слова: инклюзия; инклюзивное обучение; политика социальной адаптации лии с инвалидностью; инклюзивное образовательное пространство; система социально-экономического обеспечения лиц с инвалидностью.

Библ.: 10.

JEL Classification: I38

Target setting. In current conditions of social and economic development of the state it is difficult to talk about the possibility of financing a full and urgent transition to the form of inclusive education, therefore, by synthesizing already existing experience, given that the state policy on the introduction of inclusive education should be smooth and gradual, we propose the use of differentiated inclusive education. We consider it expedient using the term "differentiated inclusive education" as a system of state regulation in the field of providing educational services, which presupposes a standard differentiation as necessary for the training of people with special needs in particular, indirect participation in the educational process, direct participation in the educational process according to the level of knowledge, not taking into consideration age indicators or adaptation of educational institutions to the needs of participants in the educational process in all accreditation courses.

(C) Казарян Г. Г., 2019 
ТЕОРЕТИЧНІ ПРОБЛЕМИ РОЗВИТКУ НАЦІОНАЛЬНОЇ ЕКОНОМІКИ

Actual scientific research and issues analysis. Problems of social and economic adaptation of disabled persons are guarded by well-known domestic scientists: I. M. Mishchak, I. Yu. Gryshova, O. I. Gonta, O. P. Diachenko, T. Panyuk, I. O. Markina, Zh. V. Derii, O. M. Galytsky, O. Melnyk, O. V. Nikolyuk, T. M. Gnatyeva and others [1-10]. However, today, the institutional regulation of social and economic support of disabled persons in the context of the formation and implementation of the policy of social and economic adaptation of disabled persons in Ukraine needs to be improved.

Uninvestigated parts of general issue defining. Despite numerous achievements of scientists regarding the social and economic adaptation of disabled persons, the analysis of the actual situation gives grounds to assert the ineffective state policy in this area. This necessitates the search for new methods and tools for implementing such a policy, development of measures for its implementation in order to increase the efficiency of state authorities work to ensure proper living conditions of disabled persons and their inclusion and involvement in society.

The research objective. To analyze directions of the policy development of the social and economic adaptation of disabled persons in Ukraine.

Statement of the main material. At the first stage, it would be advisable to carry out a social and psychological and statistical analysis of the activities of educational institutions, identify institutions in which inclusive education elements are already being implemented and pedagogical staff have primary experience with the relevant category [2].

In order to introduce inclusive education and its standardization, there is a need for studying the starting individual indicators of children development with the peculiarities of development and their healthy peers. Monitoring the impact of integrated / inclusive education on disabled persons and their peers will provide a definition of the way to develop and implement a mechanism for their integration into general education institutions, early integration into social environment, taking into consideration their typological and individual characteristics, formation of a new philosophy of the state policy referring the disabled, implementation and dissemination of the model of differentiated inclusive education in general educational institutions.

The next step should be improvement of the legal framework for the functioning of the national education system, which would regulate principles, mechanisms and methods for the inclusive education implementation: creation of a national system for assessing the education quality, which would take into consideration the features of physical capabilities; formation of a single educational and informational environment; improvement of educational and methodological and scientific provision of educational process; improvement of material and technical base, creation of a system of free movement of participants in the educational process; development of methodological recommendations for parents, pedagogical workers, administration, auxiliary staff of inclusive educational institutions on issues of content and technology of teaching children with peculiarities of development; a clear definition of categories that cannot participate in the general educational process; constructive characteristic of the responsibility of pedagogical workers for the quality of knowledge and skills $[3 ; 6]$.

Systematic coverage of the results of experimental activities for a wide circle of the public will provide the feedback, change of stereotypical thought in relation to this issue, overcoming the problem of personal communication, the crisis of self-identity.

In the long term, it is possible to expect different variants of social and economic support of disabled persons depending on the level of financing, the state of social stability. In view of the above, it is worthwhile to formulate a strategy for creating an optimal environment for social and economic support of disabled persons.

The level of financial security can be a decisive factor. In case of inadequate funding, inertial development is possible, while integrated financing provides for the balanced development. 
ТЕОРЕТИЧНІ ПРОБЛЕМИ РОЗВИТКУ НАЦІОНАЛЬНОЇ ЕКОНОМІКИ

The path to achieving the main goal will depend on the choice of the development priorities: prompt development of educational space and the disabled employment or gradual formation of public opinion, upbringing of social culture for disabled persons. Each of the possible alternative activities has its own positive and negative options.

Therefore, in the first case, an accelerated solution of the problem is possible, which will provide certain results in a few years, but the probability of social rejection of disabled persons in the educational space sharply increases and can lead to social tension. In the second version, the probability of social tension decreases, but the achievement of the ultimate goal is significantly delayed chronologically.

In order to create an inclusive educational space in Ukraine, in our opinion, it is important to implement the following steps:

- create conditions for joining the international reporting process according to certain criteria;

- ensure a clear coordination of activities of state executive authorities, educational and rehabilitation institutions, public organizations of the disabled in solving legal, economic, organizational, scientific and methodical issues concerning disabled persons;

- develop the philosophy of inclusive education at the level of state policy, to register it legally;

- develop a nationwide concept and recommendations for the implementation of inclusive education;

- begin gradually the reforming of the education system;

- create a coordinating council on inclusive education, which would include representatives of the Ministry of Education and Science of Ukraine, the Ministry of Social Policy of Ukraine, the Ministry of Health of Ukraine, the Ministry of Ukraine for Family, Youth and Sports, NGOs, parents $[5 ; 8]$.

Consequently, at the current stage of the Ukrainian society development, the policy of social and economic support for disabled persons should be formed starting from prevention and detection of the disease to the full return of a person to society on the principle of continuity, flexibility and accessibility. The problem of social and economic support of disabled persons should be solved in a complex manner at the state level, taking into consideration individual characteristics, envisaging the transformation of social structures.

Analyzing the ways to overcome the organizational crisis in the system of state regulation, which may lead to ignoring the problems of social and economic support of disabled persons, the author notes that an important role in this context is played by the organizational component: uncertainty of strategy and goals, irrational construction of the structural and functional foundations of the system, unclear distribution and co-operation of work, this can be the cause of many conflicts of a political, economic, social, technological and psychological nature [4].

Therefore, a well-organized system of social and economic support of disabled persons can provide the necessary level of integrity and flexibility in resolving certain issues. A consistent state policy regarding social and economic support of disabled persons should be built on uniform standards, should ensure strict and obligatory compliance with regulatory requirements, and deviations from the rules must necessarily be punished strictly by law. Taking into consideration that modern levers of the process of social and economic support of disabled persons were formed during the transition period, there is a need to improve the processes of socialization. In order to increase efficiency, the need for co-ordination on macro-level measures of long-term action and directing of priority actions, clear allocation of powers at all levels has risen.

Ukraine is currently only on the path to the formation of a society of equal opportunities. The principle of equal rights implies that the needs of all are equally important; they should be the basis for determining the direction of state policy on the availability of services. People with special needs, having equal rights, have the same responsibilities; therefore, it would be logical to involve this category of citizens in solving the problems of disability. 
ТЕОРЕТИЧНІ ПРОБЛЕМИ РОЗВИТКУ НАЦІОНАЛЬНОЇ ЕКОНОМІКИ

To date, in Ukraine, the state policy on the implementation of active measures for the social and economic support of disabled persons has not been finalized; their employment remains low; low scale involvement of disabled persons in entrepreneurship; the barrier-free environment is only beginning to be formed as a means of accelerating the integration into the social life of this category of citizens; due to the lack of conditions for the effective implementation of their right to work, the full compliance with international standards of living standards for disabled persons is not ensured.

Overcoming of existing problems should be based on the creation of favorable social and economic, organizational and legal conditions for the social and economic support of disabled persons.

In our opinion, one of the areas of increasing the effectiveness of social and economic support of disabled persons is to increase the role of NGOs in solving problems. To improve their functioning, it is necessary to specify the legal, regulatory and legal foundations of activity $[5\rceil$.

Our research showed that institutional regulation of social and economic support of disabled persons should be directed in the following directions:

- providing complete architectural accessibility;

- motivation of professional activity of disabled persons;

- stimulating employers.

Institutional regulation of social and economic support of disabled persons should take into consideration the following aspects:

- state responsibility for the formation and implementation of the employment policy;

- the priority of ensuring full, productive and freely chosen employment in the process of implementing an active social and economic policy of the state;

- ensuring equal opportunities for citizens residing in Ukraine in the exercise of their constitutional right to work;

- provision of social partnership of subjects of the labor market with special needs, implementation of their right to free choice of a kind of activity according to their abilities and professional training taking into consideration personal interests and social needs, to this end, an appropriate choice of the list of types of professional activity should be ensured at the state level;

- promotion of effective employment, unemployment prevention, creation of new adapted workplaces and conditions for entrepreneurship development;

- voluntariness, lack of coercion of citizens regarding the choice of the activity sphere and workplace;

- publicity on the basis of comprehensive informing of disabled persons about the availability of vacancies;

- adherence to the complexity of measures for the regulation of the disabled employment;

- support for able-bodied disabled persons who need social protection;

- provision of preventive measures for the regulation of social and economic support of disabled persons;

- a guarantee of social and economic support of disabled persons, that is, the guarantee of jobs and profession preservation, guarantee of income receipt [4].

Depending on the state of economic development, the state of the labor market, some active and passive measures of institutional regulation of social and economic support of disabled persons are foreseen.

Active measures include:

- creation of additional and new jobs by the economy restructuring, developing private business, especially small and medium enterprises, conditions creation for foreign investment, for self-employment of disabled people, etc.;

- vocational guidance, training and retraining of personnel;

- organization of public works;

- strengthening the territorial and professional mobility of disabled persons;

- development of a separate relevant direction of the employment service, etc. 
ТЕОРЕТИЧНІ ПРОБЛЕМИ РОЗВИТКУ НАЦІОНАЛЬНОЇ ЕКОНОМІКИ

Passive measures include:

- payment of monetary aid to disabled persons;

- assistance to family members who are detained by disabled persons.

It should be emphasized that creation of new permanent and temporary jobs in modern conditions depends largely on the development of small enterprises. Nowadays in Ukraine, they account for about $60 \%$ of the total number of employed in non-state structures.

Creation of small businesses does not require a large start-up capital. At the same time, these enterprises provide with a job a significant share of temporarily unemployed citizens.

A promising direction is the organization of small enterprises by attracting to them the graduates of vocational and technical schools. Despite the relatively lower cost of jobs in the social sphere, it would be advisable to create new enterprises in the manufacturing sector. An example of such a direction of work can be the functioning of the company «NOMOS» (Director - O. Lepetyuk, lawyer), which carries out economic activity aimed at meeting the goals and objectives of the founder - Kharkiv non-governmental organization of blind lawyers. The company provides social (legal) services to citizens who are in difficult circumstances, namely: protection of rights and interests is carried out, consultations on current legislation, assistance to the use of state coercion and realization of legal responsibility of persons who resort to unlawful actions are provided (registration of legal documents, lawyer's assistance, protection of rights and interests of a person). The company broadly facilitates the employment of law students, provides jobs for a large number of people with special needs [7].

The effectiveness of small enterprises creation is also evidenced by foreign experience. Of the total number of new jobs in the industrialized countries, $60 \%$ to $80 \%$ of them are small businesses. In Germany, for example, up to $70 \%$ of the unemployed get jobs at small businesses. The progressive direction of employment regulation for people with special needs should be considered as preferential credit and tax policies for enterprises that increase the number of jobs and provide them to socially vulnerable groups of unemployed population.

An important direction of the active policy of social and economic support of disabled persons is vocational training, retraining and professional development of workers in order to create favorable conditions for large-scale deployment of processes of structural and technological restructuring of the economy, prevention of forced chronic unemployment, solution of personnel tasks related to rationalization of employment [10].

First of all, it is necessary to carry out professional training and retraining of personnel with the subsequent employment.

The system of professional training of unemployed and unoccupied disabled persons must carry out social (occupation, specialty as a means of protection against unemployment) and economic functions (development of labor potential of society, reproduction of the labor force required qualifications), supplement existing vocational training systems. It should become one of the chains of continuous learning.

The system of professional training of unemployed and unoccupied disabled persons is intended mainly for training and retraining of people who have become disabled in adulthood, based on their professional knowledge and skills, production experience. Young people with a disability who are looking for work for the first time should receive a specialty in institutions of inclusive nature.

Of great importance is the increased flexibility of the system of vocational training and retraining, first of all, by improving the system of studying the needs of the labor market and increasing the range of specialties that may be provided for the education of disabled persons. In doing so, plans and programs of training should be oriented to meet specific needs of the customer, in connection with which there is a need to simplify the system of accreditation of educational institutions. 
ТЕОРЕТИЧНІ ПРОБЛЕМИ РОЗВИТКУ НАЦІОНАЛЬНОЇ ЕКОНОМІКИ

It is worth paying attention to improving the information system on vacancies, first of all, to create an integrated labor market database containing information on the needs of enterprises in the personnel by professions and qualifications (structure of professions, level of qualifications), as well as data on the number of available and required jobs by category of staff.

Given the generally low level of material support, limited access to the Internet, low awareness of disabled persons, it is necessary to improve and diversify the forms of information services of this category in the labor market by periodically preparing and informing them about the need of enterprises in the workforce, about the need for continuing education and obtaining a competitive profession in the labor market. There is a need to expand the system of holding specialized (sectoral) and regional (inter-industry) vacancies fairs; to provide development of vocational guidance services for disabled people (informational, diagnostic, consultative, etc.).

The next requirement for social and economic support of disabled persons is the creation of barrier-free institutional infrastructure: improvement of the system for monitoring the availability of the environment; increasing the role of public organizations in checking project documentation and acceptance for the operation of new buildings; obligation of the relevant authorities to thoroughly verify compliance with the standards of public transport and places of public use. Provide architectural accessibility not only to buildings and facilities of educational, sports and recreation establishments, institutions of social protection of the population, public buildings, but also pay special attention to improving the accessibility of residential buildings, trade enterprises. Develop a system of strict control over compliance with already approved standards. It is vitally important to determine the norms of physical availability of jobs, definition of standards for workplaces, recommendations for conditions at a specialized workplace.

Development of new programs not only for the employment of disabled persons, but also creation of programs for their professional orientation, support in the workplace will enable the formation of a system of professional counseling from the school age and create a flexible system of professional support throughout life.

Development of a competitive disability monitoring system for disabled persons will significantly transform the educational system for them. By determining quantitative and qualitative characteristics of the labor market, that is, the actual number of specialists from the category of disabled persons, in conjunction with the perfect study of possible vacancies in government structures, in specialized industries, in the sphere of small and medium business, individual entrepreneurship, it will be significantly easier to identify ways to solve the problem.

When disabled persons are employed, their ability to vocational training, performance of work is assessed. Today, even disabled persons of Groups I and II, previously considered to be disabled, receive recommendations for certain types of work- this is a big step towards eliminating physical discrimination, but it is clear that such citizens can be employed in those kinds of activities and under those conditions of work that are adequate to their physical capacity, and for the employer creation of such jobs is fraught with high costs. Therefore, employment of disabled persons of Groups I and II should be stimulated accordingly.

Unification of the stimulation system of employers for employment of disabled persons is one of the defining directions of the reform of the institutional regulation of social and economic support of disabled persons. In international practice, not only administrativecompulsory, but also financial-economic and socio-psychological mechanisms of the employer's stimulation are widely used. In this context, in order to solve the problem of social and economic support of disabled persons, in our opinion, it would be expedient for the appropriate structures of executive power, to work out a system of forecasting the number of categories of disabled persons, that are able to work, develop a public investment system to create jobs for disabled people, develop the most suitable forms of employment - home work, reduced working week, day, temporary employment; introduce a system of graduates' certification by the 
ТЕОРЕТИЧНІ ПРОБЛЕМИ РОЗВИТКУ НАЦІОНАЛЬНОЇ ЕКОНОМІКИ

employer with a further assessment of the educational institution activity, which will affect the results of accreditation; take measures to support the manufacturer who uses the work of people with special needs (subsidies for hiring people with special needs above the 4 per cent quota; subsidies on wages during the first year of work of a disabled person with subsequent differentiation of its size, grants and subsidies for arrangement, re-equipment or maintenance of a specialized workplace; benefits when paying contributions for social insurance, reduction of taxes on the wage fund); develop a system of benefits, donations and subsidies for employers who take people with special needs not only to work but also to vocational training as students; create a state order for products produced with the participation of this category of population; introduce a system of state standard for hourly payment for disabled persons; work out a clear system of discrimination detection in the field of employment, strengthen state control over observance of regulatory instructions, determine effective sanctions; expand the vacancy database for people with special needs and employers; improve the system of statistical reporting on the monitoring of disability issues; introduce a system of annual incentives at the national and local levels, the most extensive use of the labor of people with special needs at all stages of production, in compliance with world standards; promote not only development of the entrepreneurship of disabled persons, but also take measures for its expansion; distribute in the mass media social advertisements of products made with the participation of disabled persons; contribute to the formation of a humane attitude of society towards this category of population; prevent the formation of social stereotypes regarding disabled persons; improve and promote competitions involving employers and disabled persons who demonstrate their professional capabilities; provide in collective agreements measures on the industrial adaptation and socialization of disabled workers; improve the mechanism of increasing employers' liability for improper implementation of the socialization of disabled workers.

In terms of reducing the financial burden on employers employing disabled persons, the state priority should be to review compensation for the impossibility of organizing such employment.

Along with the existence of the social security system, material support, charitable work, it is necessary to create a system of encouragement, promotion of unemployed disabled persons.

Construction of a socially oriented market economy is impossible without the formation of an effective system of institutional regulation of social and economic support of disabled persons. Therefore, it should be noted that it is motivation that can become a leverage that directs the development of social and economic relations from the advantage of extensive indicators in the direction of qualitative changes $[3 ; 8]$.

It is advisable, in our opinion, to take measures to develop a counseling system and specific targeted social assistance and social services for people with special needs, which requires the provision of appropriate funds in the state and local budgets, the Pension Fund of Ukraine and the budgets of funds of compulsory state insurance.

Conclusions and propositions. An important conceptual approach to shaping the social and economic support of disabled persons is the involvement of local executive authorities not only in facilitating the creation or reservation of jobs, but also in the search for markets of products (services) produced by enterprises, public organizations of the disabled, as well as in increase its competitiveness.

Separately there is a problem of elimination of natural, communication obstacles, overcoming psychological barriers to perceptions of disabled people in society, etc. It is the above-mentioned positions that, in our opinion, can contribute to the formation of a modern citizen, self-sufficient personality.

Thus, ensuring effective institutional regulation of social and economic support of disabled persons is possible only with a comprehensive approach to its solution in all segments (state, regional) in all its components (formation, implementation, control), with the participa- 
ТЕОРЕТИЧНІ ПРОБЛЕМИ РОЗВИТКУ НАЦІОНАЛЬНОЇ ЕКОНОМІКИ

tion of all interested structures (administrative, commercial, public). It is also necessary to clearly define the state policy of Ukraine in the field of disability prevention. That is why there is an urgent need to develop an appropriate strategy.

\section{References}

1. Hnatieva, T. M., Nikoliuk, O. V. (2014). Vplyv sotsialnoi vidpovidalnosti biznesu na konkurentospromozhnist pidpryiemstv ahrarnoho sektoru [Influence of social responsibility of business on competitiveness of agricultural enterprises]. Visnyk Chernihivskoho derzhavnoho tekhnolohichnoho universytetu. Seriia «Ekonomichni nauky» - Visnyk of Chernihiv State Technological University. Series "Economic sciences», 4 (76), 151-157 [in Ukrainian].

2. Gryshova, I. Yu., Shestakovska, T. L. (2017). Instytutsiini rehuliatory sotsialno-ekonomichnoho zabezpechennia osib z invalidnistiu na rynku medychnykh posluh Ukrainy [Institutional regulators of social and economic support of disabled persons in the medical services market of Ukraine]. Ekonomichnyi analiz - Economic analysis, 27 (3), 242-248 [in Ukrainian].

3. Gryshova, I. Yu., Shestakovska, T. L. (2017). Infrastrukturne zabezpechennia potreb invalidiv na rynku medychnykh posluh Ukrainy [Infrastructure support for the requirements of disabled persons in the medical services market of Ukraine]. Ekonomichnyi analiz - Economic analysis, 27 (4), 321-330 [in Ukrainian].

4. Gonta, O. I., Melnyk, A. G. (2017). Sotsialni innovatsii v orhanizatsiino- ekonomichnomu zabezpechenni reabilitatsii liudei $\mathrm{z}$ obmezhenymy fizychnymy mozhlyvostiamy [Social innovations in organizational and economic support for rehabilitation of disabled persons]. Visnyk Kharkivskoho natsionalnoho tekhnichnoho universytetu silskoho hospodarstva: ekonomichni nauky - Bulletin of Kharkiv National Technical University of Agriculture named after Petr Vasilenko, 185, 10-23 [in Ukrainian].

5. Kazarian, G. G., Gryshova, R. V. (2018). Metodolohichni pidkhody do formuvannia systemy sotsialno-ekonomichnoho zabezpechennia osib z obmezhenymy fizychnymy mozhlyvostiamy [Methodological approaches to the system formation of social and economic support of disabled persons]. Naukovi zapysky Instytutu zakonodavstva Verkhovnoi Rady Ukrainy - Scientific Papers of the Legislation Institute of the Verkhovna Rada of Ukraine, 5, 105-114 [in Ukrainian].

6. Melnyk, O. (2017). Kliuchovi aspekty trudovoi sotsializatsii invalidiv v Ukraini [Key aspects of work socialization of the disabled in Ukraine]. Problemy i perspektyvy ekonomiky ta upravlinnia Problems and prospects of economics and management, 2 (10), 42-50 [in Ukrainian].

7. Melnyk, Yu. M., Nikoliuk, O. V. (2015). Rozbudova sotsialnykh zviazkiv pidpryiemstv ahroprodovolchoi sfery [Development of social ties between agribusiness enterprises]. Biznesnavihator - Business Navigator, 1 (36), 48-52 [in Ukrainian].

8. Novikova, N. L., Galytskyi, O. M., Grishova, R. V. (2018). Derzhavni mekhanizmy rehuliuvannia sotsialno-ekonomichnoho zabezpechennia osib z invalidnistiu [State mechanisms of regulation of social and economic support of disabled persons]. Investytsii: praktyka ta dosvid - Investments: practice and experience, 20, 66-70. DOI: 10.32702/2306-6814.2018.20.66 [in Ukrainian].

9. Paniuk, T. P. (2015). Znachennia sotsialnoi vidpovidalnosti biznesu v upravlinni personalom pererobnykh pidpryiemstv [Essence of social responsibility of business in personnel management of processing enterprises]. Problemy i perspektyvy ekonomiky ta upravlinnia - Problems and prospects of economics and management, 3 (3), 120-125 [in Ukrainian].

10. Kolot, A. M. (Ed.) (2010). Sotsializatsiia vidnosyn u sferi pratsi v konteksti stiikoho rozvytku [Socialization of labor relations in the context of sustainable development]. Kyiv: KNEU [in Ukrainian].

\section{References (in language original)}

1. Гнатьєва Т. М., Ніколюк О. В. Вплив соціальної відповідальності бізнесу на конкурентоспроможність підприємств аграрного сектору. Вісник Чернігівського державного технологічного університету. Серія «Економічні науки»: науковий збірник. 2014. № 4 (76). С. 151-157.

2. Гришова І. Ю., Шестаковська Т. Л. Інституційні регулятори соціально-економічного забезпечення осіб з інвалідністю на ринку медичних послуг України. Економічний аналіз: зб. наук праць. Тернопіль, 2017. Т. 27, № 3. С. 242-248.

3. Гришова І. Ю., Шестаковська Т. Л. Інфраструктурне забезпечення потреб інвалідів на ринку медичних послуг України. Економічний аналіз: зб. наук праць. Тернопіль, 2017. Т. 27, № 4. C. 321-330. 
ТЕОРЕТИЧНІ ПРОБЛЕМИ РОЗВИТКУ НАЦІОНАЛЬНОЇ ЕКОНОМІКИ

4. Гонта О., Мельник О. Соціальні інновації в організаційно- економічному забезпеченні реабілітації людей з обмеженими фізичними можливостями. Вісник Харківського національного технічного університету сільського господарства: економічні науки. 2017. Вип. 185. С. 10-23.

5. Казарян Г. Г., Гришова Р. В. Методологічні підходи до формування системи соціальноекономічного забезпечення осіб з обмеженими фізичними можливостями. Наукові записки Інституту законодавства Верховної Ради України. 2018. № 5. С. 105-114.

6. Мельник О. Ключові аспекти трудової соціалізації інвалідів в Україні. Проблеми $i$ перспективи економіки та управління: науковий журнал. 2017. № 2 (10). С. 42-50.

7. Мельник Ю. М., Ніколюк О. В. Розбудова соціальних зв'язків підприємств агропродовольчої сфери. Бізнес-навігатор: науково-виробничий журнал. Херсон, 2015 . № 1 (36). С. 48-52.

8. Новікова Н. Л., Галицький О. М., Гришова Р. В. Державні механізми регулювання соціально-економічного забезпечення осіб з інвалідністю. Інвестищій: практика та досвід. 2018. № 20. C. 66-70. DOI: 10.32702/2306-6814.2018.20.66.

9. Панюк Т. П. Значення соціальної відповідальності бізнесу в управлінні персоналом переробних підприємств. Проблеми і перспективи економіки та управління: науковий журнал. 2015. № 3 (3). С. 120-125.

10. Соціалізація відносин у сфері праці в контексті стійкого розвитку: монографія / А. М. Колот, О. А. Грішнова, О. О. Герасименко та ін.; за наук. ред. д-ра екон. наук, проф. А. М. Колота. Київ: КНЕУ. 2010. 348 с.

Kazarian Genrikh - PhD Economics, Assistant Professor of the Department of Education Management, DNZ of the «Institute of Management Education» of the National Academy of Pedagogical Sciences of Ukraine (52-A Chichovykh Striltsiv Str., 04053 Kyiv, Ukraine).

Казарян Генріх Генріхович - кандидат економічних наук, доцент кафедри менеджменту освіти, ДНЗ «Інституту менеджменту освіти» Національної академії педагогічних наук України (вул. Січових стрільців, 52-А, м. Київ, 04053, Україна).

Казарян Генрих Генрихович - кандидат экономических наук, доцент кафедры менеджмента образования,

ГУЗ «Института менеджмента образования» Национальной академии педагогических наук Украины

(ул. Сечевых стрельцов, 52-А, г. Киев, 04053, Украина).

Kazarian, G. (2019). Development of a state policy of social adaptation of disabled persons in Ukraine. Problems and prospects of economics and management, 1 (17), 41-49. 